\title{
A New Genus of Marine Budding Phototrophic Bacteria, Rhodobium gen. nov., Which Includes Rhodobium orientis sp. nov. and Rhodobium marinum comb. nov.
}

\author{
AKIRA HIRAISHI, ${ }^{1 *}$ KATSURO URATA, ${ }^{2}$ AND TOSHIO SATOH ${ }^{3}$ \\ Laboratory of Environmental Biotechnology, Konishi Co., Sumida-ku, Tokyo 130, ${ }^{1}$ Department of \\ Materials Chemistry and Bioengineering, Oyama National College of Technology, \\ Oyama, Tochigi $323,{ }^{2}$ and Department of Biological Science, Hiroshima \\ University, Higashi-Hiroshima, Hiroshima $724,{ }^{3}$ Japan
}

\begin{abstract}
Strains of a previously undescribed species of purple nonsulfur phototrophic bacteria were isolated from coastal seawater in Japan. These new isolates were gram-negative, motile, budding rods that contained lamellar intracytoplasmic membranes and produced pink to red cultures. Cell extracts of photosynthetic cultures exhibited absorption maxima at $377,468,500,530,591,802$, and $870 \mathrm{~nm}$, indicating that bacteriochlorophyll $a$ and carotenoids of the spirilloxanthin series were present. The new isolates were halophilic, facultatively aerobic photoheterotrophs that grew anaerobically in the light or aerobically in the dark. Maximum growth occurred in the presence of 4 to $5 \% \mathrm{NaCl}$. Anaerobic growth in the dark with nitrate as a terminal electron acceptor also occurred. Various organic compounds were used as photosynthetic electron donors and carbon sources. Sulfate was used as a sulfur source. Both menaquinone 10 and ubiquinone 10 were produced; these quinones were the major quinones. A phylogenetic analysis based on 16S rRNA gene sequences revealed that strain $\mathrm{MB312}^{\mathrm{T}}$ ( $\mathrm{T}=$ type strain), a representative of the new phototrophs, was a member of a lineage that was distinct from members of the genus Rhodopseudomonas; Rhodopseudomonas marina was the closest relative. On the basis of the data described above, we propose the name Rhodobium orientis gen. nov., sp. nov. for the new isolates. We also propose that Rhodopseudomonas marina Imhoff 1983 should be transferred to the genus Rhodobium as Rhodobium marinum comb. nov.
\end{abstract}

Phototrophic purple nonsulfur bacteria with budding morphology and lamellar intracytoplasmic membranes have been classified previously in the genus Rhodopseudomonas $(21,35)$. However, the current taxonomic status of the genus Rhodopseudomonas is unsatisfactory, as members of this genus are diverse with respect to phenotypic and chemotaxonomic characteristics, natural habitats, and phylogenetic positions. Molecular phylogenetic analyses based on DNA-rRNA cistron similarities $(4)$ and 16 S rRNA catalogs $(33,37)$ and sequences $(17,29$, $36,38)$ have proven that the type species, Rhodopseudomonas palustris, is more closely related to some species of chemotrophic bacteria (e.g., Blastobacter denitrificans, Bradyrhizobium japonicum, and Nitrobacter winigradskyi) than to any other Rhodopseudomonas species in the alpha-2 subclass of the Proteobacteria. Chemotaxonomic analyses in which lipoquinone profiles were determined have revealed that ubiquinones are the only quinones produced by Rhodopseudomonas palustris, whereas other Rhodopseudomonas species also produce menaquinones and/or rhodoquinones $(11,12,19)$. Molecular and chemotaxonomic heterogeneity among Rhodopseudomonas species is also found in cytochrome $c$ size $(2,5)$, the lipid A structures of the outer membranes $(18,30,34)$, and whole-cell fatty acid profiles (23). While the type species, Rhodopseudomonas palustris, occurs in freshwater habitats, the natural habitats of other Rhodopseudomonas species differ depending on the species and include freshwater, terrestrial, and marine environments.

Recently, workers have begun to clarify the unsatisfactory taxonomy of the genus Rhodopseudomonas in part on the basis

${ }^{*}$ Corresponding author. Present address: Central Research Laboratories, Ajinomoto Co., Inc., Suzuki-cho 1-1, Kawasaki-ku, Kawasaki 210, Japan. Phone: 044-244-7181. Fax: 044-246-2867. of 16S rRNA sequence information and phenotypic and chemotaxonomic data. It has been suggested that Rhodopseudomonas blastica (6) should be reclassified as a member of the alpha-3 subclass and is closely related to Rhodobacter species $(16,24)$. It has been proposed that Rhodopseudomonas rosea (22) should be transferred to the new genus Rhodoplanes (17). The accumulated phenotypic and phylogenetic data suggest that all other previously described Rhodopseudomonas species except the type species, Rhodopseudomonas palustris, should be reclassified and placed in different new genera.

In this paper we describe the isolation and characterization of a new marine phototrophic purple nonsulfur bacterium which has budding morphology and a lamellar type of intracytoplasmic membrane arrangement. On the basis of the phenotypic criteria that have been used previously for the taxonomy of the phototrophic bacteria, this bacterium should have been classified as a marine species belonging to the genus Rhodopseudomonas. Since Rhodopseudomonas marina (18) is the only marine species among the previously described members of this genus, we compared the phenotypic, genotypic, and phylogenetic characteristics of the new marine phototrophic bacterium with the characteristics of Rhodopseudomonas marina. On the basis of our results, we propose that a new genus and species, Rhodobium orientis, should be created for the new phototrophic bacterium; strain MB312 is the type strain of this species. We also propose that Rhopseudomonas marina should be transferred to the new genus Rhodobium.

\section{MATERIALS AND METHODS}

Enrichment samples and isolation. The samples used for enrichment and isolation of phototrophic bacteria were seawater samples with sediment mud that were obtained from two different areas in Japan. One of the samples was collected from the bottom of a tidal pool (depth, ca. 30 to $50 \mathrm{~cm}$ ) in Goto Island, Nagasaki Prefecture, in August 1989, and the other was obtained from the 
bottom of a tidal pool (depth, ca. 50 to $70 \mathrm{~cm}$ ) in Makurazaki, Kagoshima Prefecture, in October 1992 Screw-cap 20-mi test tubes which contained $10 \mathrm{ml}$ of an enrichment medium consisting of mineral base RM2 (14) supplemented with $10 \mathrm{mM}$ acetate, $10 \mathrm{mM}$ succinate, $2 \mathrm{mM}$ thiosulfate, $2 \mathrm{mM}$ sodium ascorbate, $2.5 \% \mathrm{NaCl}, 0.01 \%$ yeast extract, and vitamin solution VA $(1 \mathrm{ml} / \mathrm{liter})(20)$ were inoculated with 0.1 - or 1-ml portions of seawater samples with mud, completely filled with the same medium, and then incubated at $28^{\circ} \mathrm{C}$ in the presence of 2,000 $\mathrm{x}$ of incandescent illumination. The agar shake technique (20) was used to isolate colonies from the enrichment cultures on the medium described above containing $0.8 \%$ agar. Single colonies that were pink to red were picked from the tubes and subjected to standard purification procedures by using agar plates and the GasPak anaerobic system.

Bacterial strains and cultivation. We studied three new isolates (strains $\mathrm{MB} 303, \mathrm{MB} 312^{\mathrm{T}}$ [T = type strain], and MB314) of purple nonsulfur bacteria isolated from coastal seawater samples. Some strains of Rhodopseudomonas marina were used in comparative studies. Rhodopseudomonas marina DSM $2698^{\mathrm{T}}$ and DSM 2780 were obtained from the Deutsche Sammlung von Mikroorganismen und Zellkulturen $\mathrm{GmbH}$, Braunschweig, Germany, whereas Rhodopseudomonas marina subsp. agilis ATCC 35601 was obtained from the American Type Culture Collection, Rockville, Md. Rhodopseudomonas marina E2-A was isolated by one of us (A.H.) from a marine environment. A chemically defined medium, designated MMYS-III medium, was routinely used to grow the new isolates for various tests. This medium contained mineral base RM2, $20 \mathrm{mM}$ sodium DL-malate as the carbon source, $2 \mathrm{mM}$ thiosulfate, $5 \% \mathrm{NaCl}$, and $0.1 \%$ yeast extract as the growth factor. MYS medium (14) supplemented with $2.5 \%$ $\mathrm{NaCl}$ was also used to grow Rhodopseudomonas marina strains. All media contained $1.5 \%$ agar when the organisms were grown on agar slants or plates. The strains were routinely cultivated anaerobically in the light in screw-cap test tubes or bottles filled with medium. For genetic studies, cells were harvested by centrifugating cultures at the mid-exponential phase of growth, washed with sterilized 1\% saline, resuspended either in pure water for PCR experiments or in EDTA-saline for DNA hybridization studies, and stored at $-20^{\circ} \mathrm{C}$ until they were used.

Morphology and ultrastructure. Morphology and related properties were studied by using intact cells and an Olympus phase-contrast microscope; negatively stained cells were examined with a JEOL transmission electron microscope. Gram reactions were determined by using a commercial Gram stain reagent kit (Wako Pure Chemicals, Kyoto, Japan). Intracellular photosynthetic membrane arrangement was determined by electron microscopy of ultrathin sections prepared by a standard fixation method, as previously described (13). The rapid-freezing and substitution fixation method (1) was also used to prepare samples for ultrathin-section electron microscopy. The cells in a light-limited culture were pelleted by centrifugation, immediately immobilized with agar spread on a glass slide, and frozen with a model RF-2 rapid-freezing device (Eiko Engineering Corp., Tokyo, Japan). The frozen sample was then fixed with acetone containing $2 \% \mathrm{OsO}_{4}$ in dry ice-acetone and embedded in Epon 812. Thin sections were cut with an ultramicrotome equipped with a glass knife, stained with uranyl acetate and lead citrate, and examined with a JEOL transmission electron microscope.

Phenotypic characterization. Unless indicated otherwise, all test media were incubated at $30^{\circ} \mathrm{C}$ in the presence of $5,000 \mathrm{~lx}$ of incandescent illumination. Aerobic growth in the dark was studied by using $100-\mathrm{ml}$ flasks containing $10 \mathrm{~m}$ of MMYS-III medium on a reciprocal shaker. Anaerobic growth with nitrate respiration was studied by using screw-cap test tubes that were completely filled with MMYS-III medium supplemented with either $10 \mathrm{mM}$ fructose or $10 \mathrm{mM}$ glucose and $20 \mathrm{mM}$ potassium nitrate. Tests to determine photoassimilation of organic substrates were performed in screw-cap test tubes containing mineral medium RM2 supplemented with $5 \% \mathrm{NaCl}$, a neutralized, filter-sterilized organic compound as the carbon source, and $0.01 \%$ yeast extract as the growth factor. Photoautotrophic growth was studied by using the $5 \% \mathrm{NaCl}$-containing mineral medium supplemented with either $0.5 \mathrm{mM}$ sodium sulfide (neutralized) or $2 \mathrm{mM}$ sodium thiosulfate as the electron donor, $20 \mathrm{mM}$ sodium bicarbonate (filter sterilized) as the carbon source, and $0.01 \%$ yeast extract. In all growth response tests, growth was monitored turbidometrically at $660 \mathrm{~nm}$ with a model ANA-75 spectrophotometer (Tokyo Photoelectric Co., Tokyo, Japan); the final data were obtained after 2 weeks of incubation. Test tubes in which the optical density was higher than the optical density in a negative control containing no substrate were considered positive. Absorption spectra of intact cells or cell extracts were determined with a Hitachi model U-2000 spectrophotometer. Quinones were extracted with an organic solvent mixture, purified by thin-layer chromatography, and analyzed by UV spectrophotometry and high-performance liquid chromatography (HPLC) $(11,12)$.

DNA base composition and DNA-DNA hybridization. Chromosomal DNA was extracted and purified by the method of Marmur (28). The guanine-plus-cytosine $(\mathrm{G}+\mathrm{C})$ content of DNA was determined by subjecting nuclease $\mathrm{P} 1$ hydrolysates of the DNA to HPLC, using external nucleotide standards as described previously (13). DNA-DNA reassociation studies were performed by the quantitative dot blot hybridization method with photobiotin labeling and colorimetric detection $(7,13)$.

Sequencing of 16S rRNA genes and phylogenetic analysis. 16S ribosomal DNA (rDNA) fragments that corresponded to positions 8 to 1510 on the Escherichia coli 16S rRNA sequence (3) were amplified by PCR from crude cell lysates and were sequenced directly by the cycle sequencing method modified for automated fluorescence detection with a Pharmacia laser fluorescent DNA sequencer. Detailed information concerning the PCR and sequencing procedures which we used has been given previously $(10,15)$. Sequence data were compiled and levels of binary sequence similarity were calculated with the GENETYX program package (Software Development Co., Tokyo, Japan). The CLUSTAL V program (9) was used to align multiple sequences, to calculate nucleotide substitution rates $\left(K_{\text {nuc }}\right.$ values) (25), to construct a neighbor-joining phylogenetic tree (31), and to statistically evaluate the tree topology by bootstrapping (8). Alignment positions that included gaps and/or unidentified bases were not taken into consideration for the calculations.

Nucleotide sequence accession numbers. The $16 \mathrm{~S}$ rDNA sequences determined in this study have been deposited in the DDBJ, EMBL, GSDB, and NCBI nucleotide sequence databases under accession numbers D30790 to D30792. The accession number for the Rhodopseudomonas marina subsp. agilis nucleotide sequence described previously is M27534. The accession numbers for the sequences used in the phylogenetic analysis are as follows: strain MB312 ${ }^{\mathrm{T}}, \mathrm{D} 30792$; Rhodopseudomonas marina DSM 2698 ${ }^{\mathrm{T}}$, D30790; Rhodopseudomonas marina ATCC 35601, D30791; Rhodopseudomonas acidophila, M34128; Rhodomicrobium vannielii, M34127; Rhodoplanes roseus, D25313; Rhodopseudomonas viridis, D25314; Rhodopseudomonas palustris, D25312; Bradyrhizobium japonicum, X66024; Rhodobacter capsulatus, D16428; Rhodobacter blasticus, D16429; Rhodovulum sulfidophilum, D16423; Erythrobacter longus, M59062; Rhodospirillum salexigens, M59070; Rhodospirillum rubrum, M32020; and Rhodopila globiformis, M59066. The sequence of Methylobacterium organophilum has been determined but has not been deposited in a database (Hiraishi, unpublished data).

\section{RESULTS}

Enrichment and isolation. Most of the test tubes inoculated with seawater samples exhibited positive results for enrichment of phototrophic bacteria after 1 to 3 weeks of incubation, as indicated by pink to red growth. An agar shake dilution series was prepared with $0.1-\mathrm{ml}$ portions of each of the enrichment cultures, and separated pink colonies were obtained in the test tubes at high dilutions. Three representative colonies recovered from each of the two seawater samples were purified for taxonomic studies. However, one-half of the isolates were lost during subculturing, perhaps because of unfavorable growth conditions (e.g., low salinity) at the initial stage of the study. As a result of these procedures, one isolate obtained from Goto Island (isolate MB303) and two isolates obtained from Makurazaki (isolates MB312 ${ }^{\mathrm{T}}$ and MB314) were successfully used for further studies.

Morphology and ultrastructure. The cells of all three isolates were gram negative, rod shaped, 0.7 to $0.9 \mu \mathrm{m}$ wide, and 1.5 to $3.2 \mu \mathrm{m}$ long (Fig. 1A). These organisms reproduced by budding and exhibited polar growth. The mode of budding appeared to be the sessile type and was similar to the mode of budding of Rhodopseudomonas marina and Rhodoplanes roseus. All isolates were motile by means of flagella. However, it was rather difficult to determine the type of flagella definitely, because electron microscopy revealed only a few flagellated cells and many loose flagella. Although the cells had single polar flagella, we could not eliminate the possibility that the isolates have subpolar, lateral, or randomly distributed flagella, like Rhodopseudomonas marina and Rhodoplanes elegans. Ultrathin-section electron microscopy revealed that the intracytoplasmic membrane arrangement in the cells of the isolates was lamellar (Fig. 1B, arrowhead) and resembled the arrangement found in Rhodopseudomonas marina. The photosynthetic membranes of the isolates were difficult to find when we examined thin sections prepared by the standard fixation method because of degradation of structures during the slow fixation procedure. The use of the rapid-freezing and substitution fixation technique (1) overcame this problem.

Photopigments and quinones. Mass cultures of the isolates were pink to red when they were grown anaerobically in the light. In this respect, the new isolates are similar to the marine phototroph Rhodopseudomonas marina. However, the isolates were easily differentiated from the latter species by their ab- 

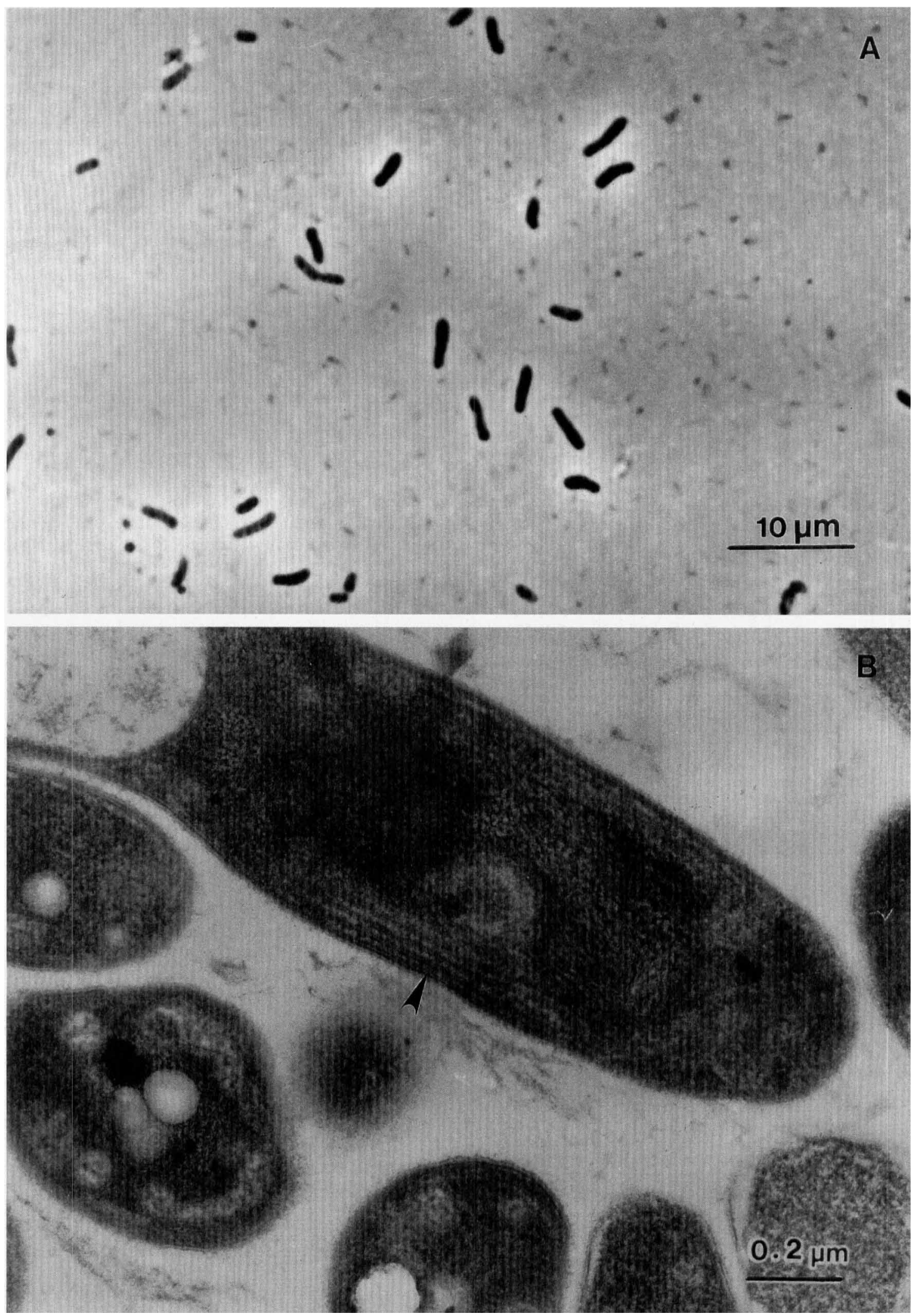

FIG. 1. Phase-contrast photomicrograph of intact cells (A) and transmission electron micrograph of an ultrathin section of cells (B), showing the general morphology and ultrastructure of a representative of the new isolates (strain MB312 $2^{\mathrm{T}}$ ). 


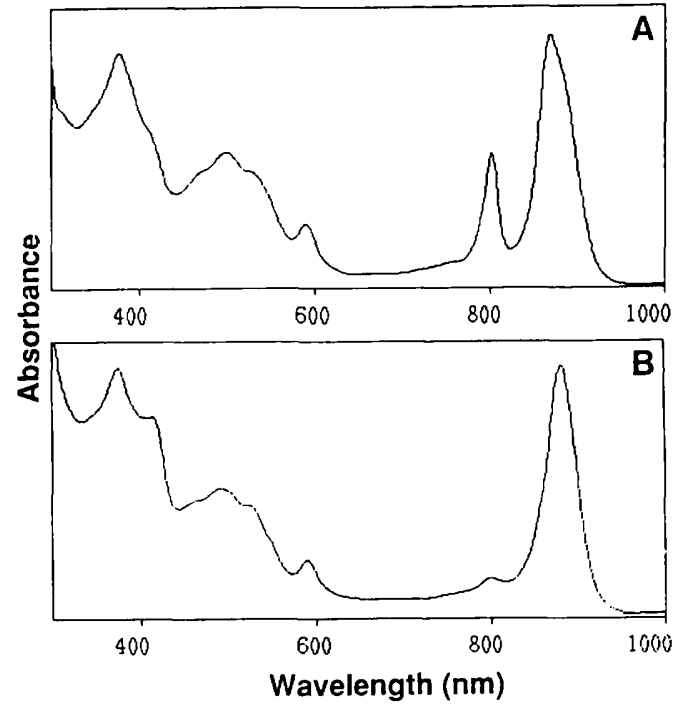

FIG. 2. Absorption spectra of cell extracts of strain $\mathrm{MB}^{2} 12^{\mathrm{T}}$ (A) and Rhodopseudomonas marina DSM $2698^{\mathbf{T}}$ (B).

sorption spectra. A cell extract of strain $\mathrm{MB} 312^{\mathrm{T}}$, a representative of the new isolates, had absorption maxima at 377,468 , $500,530,591,802$, and $870 \mathrm{~nm}$, indicating that bacteriochlorophyll $a$ and carotenoids belonging to the spirilloxanthin group were present (Fig. 2A). A cell extract of Rhodopseudomonas marina was characterized by its low level of absorption at $803 \mathrm{~nm}$ and the presence of an absorption maximum at 883 nm (Fig. 2B), like the absorption spectrum pattern of Rhodospirillum rubrum.

Thin-layer chromatography and spectrophotometry of the lipid extracts revealed that both ubiquinones and menaquinones were present; the molar ratio of menaquinones to ubiquinones was 1.0 to 1.5 in all isolates. The major homologs were ubiquinone 10 and menaquinone 10 , as determined by HPLC.

Growth and physiological characteristics. All isolates were facultatively aerobic photoheterotrophs that were able to grow anaerobically in the light or aerobically in the dark at the full oxygen tension found in air. When the organisms were grown phototrophically in MMYS-III medium, they exhibited a doubling time of 5 to $9 \mathrm{~h}$. It was interesting that the isolates were also able to grow under anaerobic conditions in the dark, provided that nitrate was added as a terminal electron acceptor. However, the denitrifying growth of the new isolates was much slower and weaker than the denitrifying growth of Rhodobacter sphaeroides IL106, the first strain reported to be a photodenitrifier (32), and seemed to be comparable to the denitrifying growth of denitrifying Rhodopseudomonas palustris strains (26) and Rhodoplanes species (17). Fermentative growth in the dark with glucose or fructose was not observed. Concurrent studies showed that all of the Rhodopseudomonas marina strains tested, including strain ATCC 35601, were able to grow fermentatively on fructose but not anaerobically by nitrate respiration. Our results concerning fermentative growth of Rhodopseudomonas marina subsp. agilis ATCC 35601 differ from the results of Mangels et al. (27).

Our new isolates were mesophilic, neutrophilic, and halophilic. The optimal growth temperature ranged from 30 to $35^{\circ} \mathrm{C}$. Growth occurred at $\mathrm{pH}$ values between 6 and 8.5 (optimum $\mathrm{pH}, 7.0$ to 7.5 ) but not at $\mathrm{pH} 5$ or 9 . The isolates grew in the presence of 2 to $8 \% \mathrm{NaCl}$, and maximum growth occurred
TABLE 1. Utilization of various compounds as electron donors and carbon sources by the new isolates ${ }^{a}$

\begin{tabular}{|c|c|c|c|}
\hline \multirow{2}{*}{$\begin{array}{l}\text { Electron donor and } \\
\text { carbon source }^{b}\end{array}$} & \multicolumn{3}{|c|}{ Utilization by: } \\
\hline & $\begin{array}{c}\text { Strain } \\
\text { MB303 }\end{array}$ & 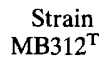 & $\begin{array}{r}\text { Strain } \\
\text { MB314 }\end{array}$ \\
\hline \multicolumn{4}{|l|}{ Organic acids } \\
\hline Formate & - & - & - \\
\hline Acetate & +++ & +++ & +++ \\
\hline Propionate $(0.05 \%)$ & - & - & - \\
\hline Butyrate $(0.05 \%)$ & ++ & + & + \\
\hline Valerate $(0.05 \%)$ & + & + & + \\
\hline Caproate $(0.05 \%)$ & + & ++ & + \\
\hline Caprylate $(0.05 \%)$ & - & - & - \\
\hline Lactate & +++ & $++t$ & +++ \\
\hline Pyruvate & +++ & +++ & +++ \\
\hline Citrate & \pm & - & - \\
\hline Succinate & +++ & +++ & +++ \\
\hline Fumarate & +++ & +++ & +++ \\
\hline Malate & +++ & +++ & +++ \\
\hline Tartrate & - & - & - \\
\hline Benzoate $(0.05 \%)$ & - & - & - \\
\hline \multicolumn{4}{|l|}{ Sugars and alcohols } \\
\hline L-Arabinose & \pm & - & - \\
\hline D-Xylose & +++ & + & + \\
\hline Fructose & +++ & ++ & ++ \\
\hline Glucose & +++ & $++t$ & +++ \\
\hline Galactose & \pm & \pm & \pm \\
\hline Mannose & \pm & \pm & \pm \\
\hline Mannitol & \pm & + & + \\
\hline Sorbitol & + & ++ & + \\
\hline Glycerol & - & - & - \\
\hline Methanol & - & - & - \\
\hline Ethanol & - & - & - \\
\hline \multicolumn{4}{|l|}{ Other compounds } \\
\hline Glutamate & + & - & - \\
\hline Casamino Acids & \pm & \pm & \pm \\
\hline Peptone & ++ & ++ & ++ \\
\hline Yeast extract & +++ & +++ & ++ \\
\hline Thiosulfate $(2 \mathrm{mM})$ & ++ & + & + \\
\hline Sulfide $(0.5 \mathrm{mM})$ & \pm & \pm & \pm \\
\hline
\end{tabular}

${ }^{a}+++$, good growth (optical density at $660 \mathrm{~nm},>0.5$ ) $;++$, moderate growth (optical density at $660 \mathrm{~nm}, 0.2$ to 0.5 ); + , poor growth (optical density at $660 \mathrm{~nm}$, 0.1 to 0.2$) ; \pm$, negligible growth (optical density at $660 \mathrm{~nm},<0.1$ ); - , no growth

${ }^{b}$ All substrates were added at a concentration of $0.2 \%$, unless indicated otherwise.

in the presence of 4 to $5 \% \mathrm{NaCl}$. The isolates required biotin and $p$-aminobenzoic acid as growth factors, but these compounds could be replaced by $0.01 \%$ yeast extract. Addition of $0.05 \%$ yeast extract to the medium enhanced growth considerably.

The results of tests to determine utilization of electron donors and carbon sources under phototrophic growth conditions are shown in Table 1. The good carbon sources were acetate, lactate, pyruvate, succinate, fumarate, malate, fructose, glucose, peptone, and yeast extract. Moderate growth occurred with butyrate, valerate, caproate, xylose, mannitol, and sorbitol. When $2 \mathrm{mM}$ thiosulfate was added to the basal medium consisting of mineral salts and $0.01 \%$ yeast extract, weak but significant phototrophic growth of the isolates occurred. This observation suggests that our isolates were able to grow autotrophically with thiosulfate as an electron donor, although we did not confirm that these organisms oxidized thiosulfate. It was not clear whether the isolates were able to grow photoautotrophically with sulfide as the electron donor when the test was performed with $0.5 \mathrm{mM}$ sodium sulfide in batch cultures. 
Our isolates used ammonium salts as nitrogen sources and sulfate and thiosulfate as sulfur sources.

Phylogenetic relationships. In the phylogenetic analysis, $16 \mathrm{~S}$ rRNA genes from three strains, new isolate MB312 ${ }^{\mathrm{T}}$, Rhodopseudomonas marina DSM $2698^{\mathrm{T}}$, and Rhodopseudomonas marina subsp. agilis ATCC 35601, were amplified by the PCR and sequenced directly by a combined method consisting of cycle sequencing and automated fluorescence detection. Our sequencing strategy generated almost complete $16 \mathrm{~S}$ rDNA sequences for ca. $95 \%$ of the entire molecule (i.e., 1,408 bases for strain $\mathrm{MB} 312^{\mathrm{T}}$ and 1,390 bases for the two Rhodopseudomonas marina strains). The shorter primary sequence of Rhodopseudomonas marina compared with the primary sequence of strain MB312 ${ }^{\mathrm{T}}$ was due to a 21-base deletion in the conserved region between positions 1256 and 1281 (E. coli numbering), like the deletion found in the phototrophic members of the alpha-3 subclass (16) of the Proteobacteria. The primary sequences of the two Rhodopseudomonas marina strains examined were identical, and our data confirmed the sequence of Rhodopseudomonas marina subsp. agilis reported previously, except at a few positions.

The new 16S rDNA sequences which we determined were aligned and compared with a data set consisting of 14 sequences available from databases, including the sequences of 11 anaerobic phototrophic bacterial species and 3 related species belonging to the alpha subclass of the Proteobacteria. Table 2 shows the levels of binary sequence similarity and the evolutionary distances ( $K_{\text {nuc }}$ values) based on the 1,265 positions of the entire sequence set that could be aligned. Strain MB312 $2^{\mathrm{T}}$ exhibited the highest level of sequence similarity to Rhodopseudomonas marina (93.8\%) among the organisms compared. The levels of sequence similarity between strain $\mathrm{MB} 312^{\mathrm{T}}$ and the other species were much lower (less than 91\%).

Figure 3 shows a phylogenetic tree which was reconstructed on the basis of the distance matrix values shown in Table 2. Strain MB312 $2^{\mathrm{T}}$ formed a cluster with Rhodopseudomonas marina, and this cluster was distinct from the previously described species of phototrophic bacteria and their relatives belonging to the alpha subclass of the Proteobacteria. However, the monophyletic relationship between the new isolate and Rhodopseudomonas marina seemed to be unstable, as suggested by the deep branching of the two taxa within the cluster and by the relatively low level $(61.3 \%)$ of bootstrap confidence that supported this node (Fig. 3, arrow).

We determined DNA base ratios and performed DNADNA hybridization assays to obtain more detailed information about the genetic relationship between the new marine group and Rhodopseudomonas marina (Table 3). The strains belonging to the new marine group had DNA G+C contents of 65.2 to $65.7 \mathrm{~mol} \%$; these values were 2 to $3 \mathrm{~mol} \%$ higher than the values obtained for Rhodopseudomonas marina. The levels of genomic DNA hybridization between strains belonging to the same group were more than $70 \%$, but the levels of genomic DNA hybridization between strains belonging to different groups were low $(<16 \%)$, suggesting that the organisms belonging to the two taxa represent distinct species.

\section{DISCUSSION}

We successfully characterized new marine isolates of budding purple nonsulfur bacteria and compared these organisms with Rhodopseudomonas marina, which is the only previously described marine species of budding phototrophic bacteria. Our new isolates, which are genetically conspecific, are facultatively aerobic, halophilic photoheterotrophs that produce pink to red cultures, form lamellar photosynthetic membranes, produce bacteriochlorophyll $a$ and carotenoids belonging to the spirilloxanthin group, and contain ubiquinone 10 and menaquinone 10 as their major quinones. In these respects, the new isolates resemble Rhodopseudomonas marina. On the basis of our results and previous data for Rhodopseudomonas marina (18), however, we identified differences between the two taxa in a number of phenotypic characteristics, including $\mathrm{NaCl}$ range for growth, absorption spectrum pattern, denitrification, fermentative growth on hexoses, and photoassimilation of some organic compounds, including propionate and ethanol. It is also easy to differentiate our isolates from Rhodopseudomonas species (35) and Rhodoplanes species (17) on the basis of their natural habitats and basic phenotypic traits.

The molecular genetic data based on 16S rRNA gene sequences and DNA-DNA hybridization results demonstrated that the new isolates are most closely related to, but are genetically different from Rhodopseudomonas marina. These data led us to conclude unequivocally that the new isolates belong to a previously undescribed species of marine phototrophic bacteria.

The available molecular and chemotaxonomic information strongly suggests that most Rhodopseudomonas species, including the marine species Rhodopseudomonas marina, should be reclassified and placed in different new genera (17). We determined that the new marine isolates should also be classified in a genus other than the genus Rhodopseudomonas. The remaining problem which we had to consider was whether our isolates should be united with Rhodopseudomonas marina in a single new genus. The primary $16 \mathrm{~S}$ rDNA structure of strain $\mathrm{MB} 312^{\mathrm{T}}$, a representative of the new isolates, is most similar to the primary $16 \mathrm{~S}$ rDNA structure of Rhodopseudomonas marina, but the level of sequence similarity between these two organisms $(93.8 \%)$ appears to be relatively low for members of the same genus. Also, the secondary 16S rRNA structure of Rhodopseudomonas marina differs from the secondary $16 \mathrm{~S}$ rRNA structure of the new isolate in that the conserved helix region between positions 1256 and 1281 ( $E$. coli numbering) is largely deleted. Our phylogenetic analysis with bootstrapping revealed that strain $\mathrm{MB} 312^{\mathrm{T}}$ forms a cluster with Rhodopseudomonas marina, but the relationship is not very stable as a monophyletic unit. Therefore, we thought that it would be possible to classify the new isolates and Rhodopseudomonas marina in two new genera as long as only molecular data were used for generic assignment.

However, we concluded that the new isolates and Rhodopseudomonas marina, should be placed in one genus at this time, because the phenotypic differences between the two taxa found so far seem to be too small to warrant generic separation. Below we propose the name Rhodobium orientis gen. nov., sp. nov. to accommodate the new marine phototrophs; the type strain is strain MB312. We also propose that Rhodopseudomonas marina Imhoff 1983 should be transferred to the new genus Rhodobium as Rhodobium marinum comb. nov. Table 4 summarizes characteristics which differentiate Rhodobium orientis, Rhodobium marinum, and some other species of budding phototrophic bacteria.

Description of Rhodobium gen. nov. Rhodobium (Rho.do'bi.um. Gr. n. rhodos, rose; Gr. n. bios, life; M.L. n. Rhodobium, red life). Cells are ovoid to rod shaped, 0.7 to 0.9 $\mu \mathrm{m}$ wide, and 1.0 to $3.2 \mu \mathrm{m}$ long. Motile by means of polar or randomly distributed flagella. Cells multiply by budding and asymmetric cell division. Rosette formation is rare. Gram negative. Phototrophically grown cells contain intracytoplasmic membranes of the lamellar type together with bacteriochlorophyll $a$ and carotenoids belonging to the spirilloxanthin series. 


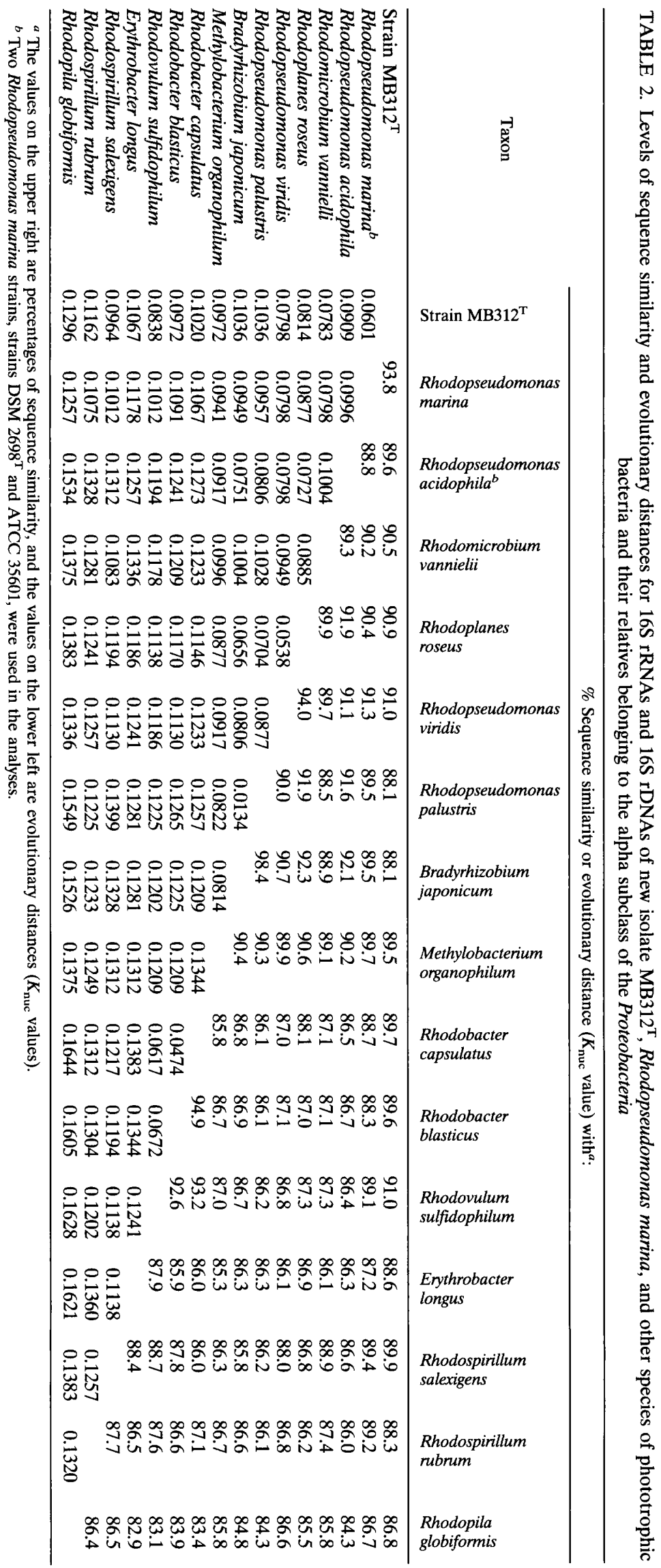




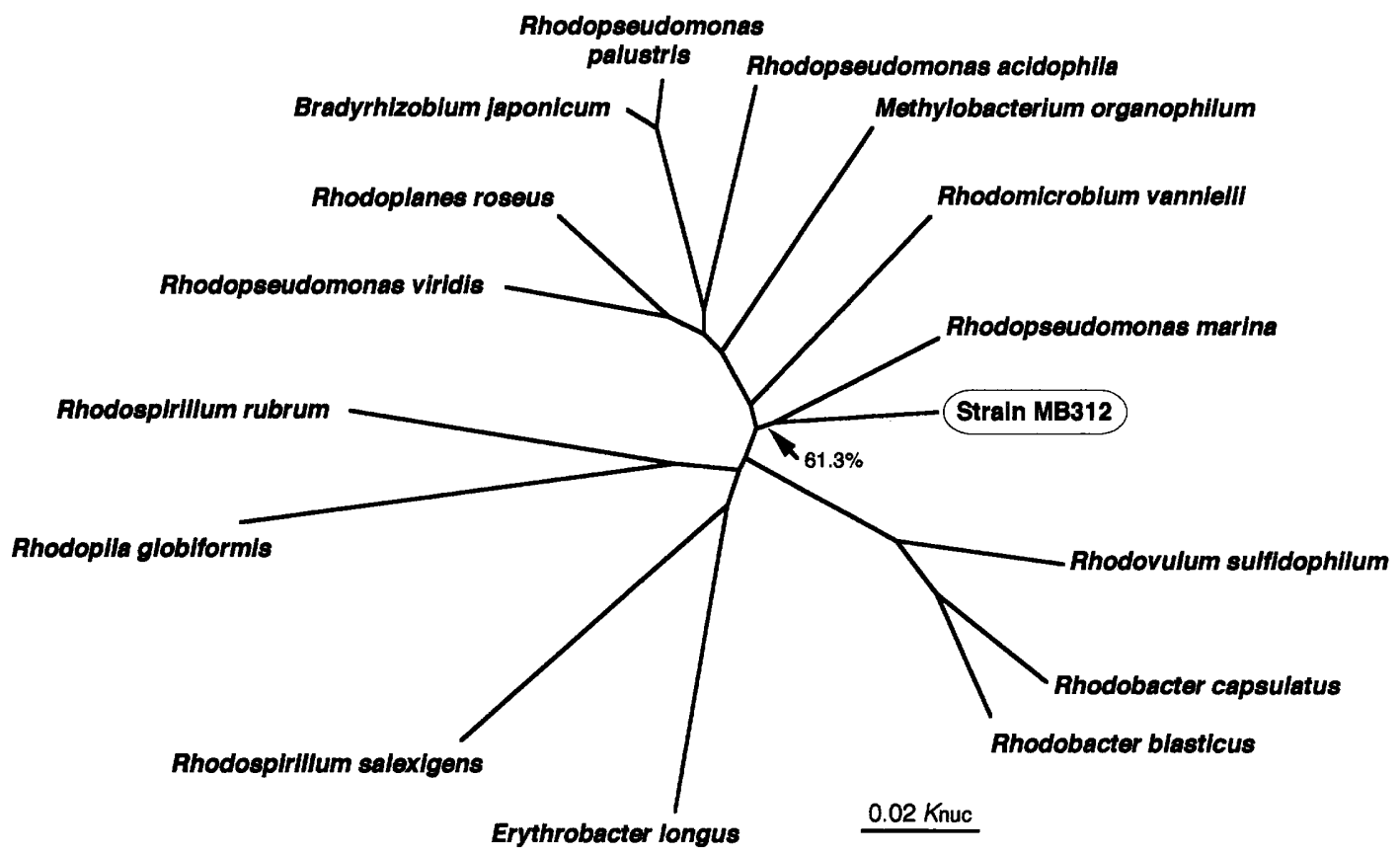

FIG. 3. Unrooted distance matrix tree showing phylogenetic affiliations of strain $\mathrm{MB} 32^{\mathrm{T}}$, Rhodopseudomonas marina, and other species of phototrophic bacteria and their relatives in the alpha subclass of the Proteobacteria. A bootstrap confidence value (obtained by using the results of 1,000 bootstrapped trials) is given at the node which separates strain MB312 ${ }^{\mathrm{T}}$ and Rhodopseudomonas marina as a monophyletic fraction.

Facultative photoheterotrophs that grow anaerobically in the light or aerobically in the dark. Photosynthetic cultures are pink to red, while aerobic chemotrophic cultures are colorless. Mesophilic and halophilic. Optimal growth occurs at 25 to $35^{\circ} \mathrm{C}$, at $\mathrm{pH} 6.9$ to 7.5 , and in the presence of 1 to $5 \% \mathrm{NaCl}$. Photoorganotrophy with simple organic compounds as carbon sources is the preferred mode of growth. Ubiquinone 10 and menaquinone 10 are the major quinones. The $\mathrm{G}+\mathrm{C}$ contents of the DNAs range from 61.5 to $65.7 \mathrm{~mol} \%$. The phylogenetic position is in the alpha- 2 subclass of the Proteobacteria.

The type species is Rhodobium orientis.

Description of Rhodobium orientis sp. nov. Rhodobium orientis (or.i.en'tis. L. part. adj. orientis, of the orient). The basic morphological fine-structure, physiological, and chemotaxonomic characteristics are the same as those described above for the genus. Cells are rod shaped, 0.7 to $0.9 \mu \mathrm{m}$ wide, and 1.5 to

TABLE 3. Levels of genomic DNA relatedness among the new isolates and Rhodopseudomonas marina strains

\begin{tabular}{|c|c|c|c|}
\hline \multirow{2}{*}{ Organism } & \multirow{2}{*}{$\begin{array}{l}\mathrm{G}+\mathrm{C} \text { content } \\
(\mathrm{mol} \%)\end{array}$} & \multicolumn{2}{|c|}{$\begin{array}{l}\text { \% Hybridization with } \\
\text { labeled DNA from: }\end{array}$} \\
\hline & & $\begin{array}{l}\text { Strain } \\
\text { MB312 }^{\mathrm{T}}\end{array}$ & $\begin{array}{l}\text { Strain DSM } \\
2698^{\mathrm{T}}\end{array}$ \\
\hline \multicolumn{4}{|l|}{ New isolates } \\
\hline MB303 & 65.7 & 72 & 16 \\
\hline $\mathrm{MB} 312^{\mathrm{T}}$ & 65.3 & 100 & 14 \\
\hline MB314 & 65.2 & 104 & 14 \\
\hline \multicolumn{4}{|c|}{ Rhodopseudomonas marina strains } \\
\hline DSM $2698^{T}$ & $63.4(63.6)^{a}$ & 10 & 100 \\
\hline DSM 2780 & $62.4(61.5)^{a}$ & 10 & 91 \\
\hline E2-A & 63.8 & 11 & 82 \\
\hline ATCC $35601^{b}$ & $64.1(64.1)^{c}$ & 12 & 74 \\
\hline
\end{tabular}

${ }_{b}^{a}$ The value in parentheses is from reference 18.

${ }^{b}$ Rhodopseudomonas marina subsp. agilis.

${ }^{c}$ The value in parentheses is from reference 27 .
$3.2 \mu \mathrm{m}$ long. The absorption maxima of cell extracts are at 377 , $468,500,530,591,802$, and $870 \mathrm{~nm}$. Biotin and $p$-aminobenzoic acid are required as growth factors, and growth is stimulated considerably by $0.05 \%$ yeast extract. Optimal growth occurs at 30 to $35^{\circ} \mathrm{C}$, at $\mathrm{pH} 7.0$ to 7.5 , and in the presence of 4 to $5 \% \mathrm{NaCl}$; growth occurs in the presence of 2 to $8 \% \mathrm{NaCl}$. Anaerobic growth in the dark with nitrate as a terminal electron acceptor is possible; denitrification occurs. Good carbon sources are acetate, lactate, pyruvate, succinate, fumarate, malate, fructose, glucose, peptone, and yeast extract. Moderate growth occurs with butyrate, valerate, caproate, xylose, mannitol, and sorbitol. Formate, propionate, caprylate, citrate, tartrate, benzoate, arabinose, galactose, mannose, glycerol, methanol, ethanol, and Casamino Acids are not utilized. Photoautotrophic growth with thiosulfate as the electron donor occurs in the presence of $0.01 \%$ yeast extract. Ammonium salts are used as nitrogen sources. Sulfate is assimilated. The $\mathrm{G}+\mathrm{C}$ contents of the DNAs range from 65.2 to $65.7 \mathrm{~mol} \%$ (as determined by HPLC).

Habitats: seawater pools and similar marine environments.

The type strain is strain MB312, which has been deposited in the Japan Collection of Microorganisms, RIKEN, Wako, Japan, as Rhodobium orientis JCM 9337.

Description of Rhodobium marinum comb. nov. Rhodobium marinum (Rhodopseudomonas marina Imhoff 1983) (ma.ri' num. L. adj. marinum, of the sea, marine). The characteristics described below are based on information obtained from previous reports $(18,27)$ and in this study. The basic morphological fine-structure, physiological, and chemotaxonomic characteristics are the same as those described above for the genus. Cells are ovoid to rod shaped, 0.7 to $0.9 \mu \mathrm{m}$ wide, and 1.0 to 2.5 $\mu \mathrm{m}$ long. Rosette formation is not observed. The absorption maxima of living cells or cell extracts are at $375,483,516,533$, 590,803 , and $883 \mathrm{~nm}$, and there is a low absorption maximum at around $800 \mathrm{~nm}$. Growth factors are required. Optimal growth occurs at 25 to $30^{\circ} \mathrm{C}$, at $\mathrm{pH} 6.9$ to 7.1 , and in the 
TABLE 4. Differential characteristics of Rhodobium orientis gen. nov., sp. nov., Rhodobium marinum comb. nov., and some other budding phototrophic bacteria ${ }^{a}$

\begin{tabular}{|c|c|c|c|c|c|c|}
\hline Characteristic & $\begin{array}{l}\text { Rhodobium } \\
\text { orientis }\end{array}$ & $\begin{array}{l}\text { Rhodobium } \\
\text { marinum }\end{array}$ & $\begin{array}{l}\text { Rhodoplanes } \\
\text { roseus }\end{array}$ & $\begin{array}{l}\text { Rhodoplanes } \\
\text { elegans }\end{array}$ & $\begin{array}{c}\text { Rhodopseudomonas } \\
\text { palustris }\end{array}$ & $\begin{array}{l}\text { Rhodopseudomonas } \\
\text { acidophila }\end{array}$ \\
\hline Cell diam $(\mu \mathrm{m})$ & $0.7-0.9$ & $0.7-0.9$ & 1.0 & $0.8-1.0$ & $0.6-0.8$ & $1.0-1.2$ \\
\hline Type of budding & Sessile & Sessile & Sessile & Tube & Tube & Sessile \\
\hline Rosette formation & $-1+$ & - & - & + & + & - \\
\hline Color(s) of cultures & Pink, red & Pink, red & Pink & Pink & Red & Red \\
\hline $\begin{array}{l}\text { Low absorption } \\
\text { maximum at ca. } \\
800 \mathrm{~nm}\end{array}$ & - & + & - & - & - & - \\
\hline Salt requirement & + & + & - & - & - & - \\
\hline Acidophilic & - & - & - & - & - & + \\
\hline Denitrification & + & - & + & + & $-1+$ & - \\
\hline $\begin{array}{l}\text { Fermentative growth on } \\
\text { fructose }\end{array}$ & - & + & - & - & - & - \\
\hline Vitamin(s) required & $p$-ABA, biotin & Complex & Biotin & $\begin{array}{l}p-\mathrm{ABA} \\
\text { biotin }\end{array}$ & $p$-ABA (biotin) & None \\
\hline \multicolumn{7}{|l|}{ Utilization of: } \\
\hline Benzoate & - & - & - & - & + & - \\
\hline Citrate & - & $-1+$ & + & + & + & - \\
\hline Formate & - & + & - & - & - & - \\
\hline Tartrate & - & - & + & + & - & - \\
\hline Glucose & + & + & - & - & - & - \\
\hline Thiosulfate & + & - & + & + & + & - \\
\hline Major quinone(s) & Q-10, MK-10 & $\mathrm{Q}-10, \mathrm{MK}-10$ & Q-10, RQ-10 & Q-10, RQ-10 & Q-10 & Q-10, MK-10, RQ-10 \\
\hline $\mathrm{G}+\mathrm{C}$ content $(\mathrm{mol} \%)$ & $65.2-65.7$ & $61.5-64.1$ & 66.5 & $69.6-69.7$ & $64.1-66.3$ & $62.2-66.8$ \\
\hline Habitat & Seawater & Seawater & Freshwater & Freshwater & Freshwater & Freshwater \\
\hline
\end{tabular}

$a+$, positive; - , negative; $-1+$, most strains are negative but some strains are positive; $p$-ABA, $p$-aminobenzoic acid; (biotin), biotin is required by some strains; $\mathrm{Q}-10$ ubiquinone 10; MK-10, menaquinones 10; RQ-10, rhodoquinone 10. Information was obtained from references $11,17,18,22$, and 35.

presence of 1 to $5 \% \mathrm{NaCl}$. Fermentative growth in the dark is possible at the expense of fructose. Denitrification does not occur. All or most strains use the following compounds as electron donors and carbon sources: acetate, propionate, butyrate, valerate, caproate, lactate, pyruvate, succinate, fumarate, malate, ascorbate, fructose, glucose, sucrose, mannitol, sorbitol, ethanol, propanol, and Casamino Acids. Weak growth occurs with formate, galactose, and glycerol. Benzoate, tartrate, and methanol are not utilized. Sulfide is used as an electron donor for phototrophic growth. No photoautotrophic growth occurs with thiosulfate as the electron donor. Ammonium salts are used as nitrogen sources. Sulfate is assimilated. The $\mathrm{G}+\mathrm{C}$ contents of the DNAs range from 62.4 to $64.1 \mathrm{~mol} \%$ (as determined by HPLC) or from 61.5 to $64.1 \mathrm{~mol} \%$ (as determined by the thermal denaturation method).

Habitats: marine and moderately hypersaline waters and marine coastal sediments.

The type strain is DSM 2698 (= ATCC $35675=$ Imhoff BN 126).

\section{REFERENCES}

1. Amako, K., and A. Takade. 1985. The fine structure of Bacillus subtilis revealed by the rapid-freezing and substitution-fixation method. J. Electron Microsc. 34:13-17.

2. Ambler, R. P., M. Daniel, J. Hermoso, T. E. Meyer, R. G. Bartsch, and M. D. Kamen. 1979. Cytochrome $c_{2}$ sequence variation among the recognized species of purple nonsulphur photosynthetic bacteria. Nature (London) 278: $659-660$.

3. Brosius, J., J. L. Palmer, J. P. Kennedy, and H. F. Noller. 1978. Complete nucleotide sequence of a $16 \mathrm{~S}$ ribosomal RNA gene from Escherichia coli. Proc. Natl. Acad. Sci. USA 75:4801-4805.

4. De Ley, J. 1992. The proteobacteria: ribosomal RNA cistron similarities and bacterial taxonomy, p. 2111-2140. In A. Balows, H. G. Trüper, M. Dworkin, W. Harder, and K. H. Schleifer (ed.), The prokaryotes, 2nd ed. SpringerVerlag, Berlin.

5. Dickerson, R. E. 1980. Evolution and gene transfer in purple photosynthetic bacteria. Nature (London) 283:210-212

6. Eckersley, K., and C. S. Dow. 1980. Rhodopseudomonas blastica sp. nov.: a member of the Rhodospirillaceae. J. Gen. Microbiol. 119:465-473.

7. Ezaki, T., S. Dejsirilert, H. Yamamoto, N. Takeuchi, S. Liu, and E. Yabuu- chi. 1988. Simple and rapid genetic identification of Legionella species with photobiotin-labeled DNA. J. Gen. Appl. Microbiol. 34:191-199.

8. Felsenstein, J. 1985. Confidence limits on phylogenies: an approach using the bootstrap. Evolution 39:783-791.

9. Higgins, D. G., A. J. Bleasby, and R. Fuchs. 1992. CLUSTAL V: improved software for multiple sequence alignment. Comput. Appl. Biosci. 8:189-191.

10. Hiraishi, A. 1992. Direct automated sequencing of $16 \mathrm{~S}$ rDNA amplified by polymerase chain reaction from bacterial cultures without DNA purification. Lett. Appl. Microbiol. 15:210-213.

11. Hiraishi, A., and Y. Hoshino. 1984. Distribution of rhodoquinone in Rhodospirillaceae and its taxonomic implications. J. Gen. Appl. Microbiol. 30: $435-448$.

12. Hiraishi, A., Y. Hoshino, and H. Kitamura. 1984. Isoprenoid quinone composition in the classification of Rhodospirillaceae. J. Gen. Appl. Microbiol. 30:197-210.

13. Hiraishi, A., Y. Hoshino, and T. Satoh. 1991. Rhodoferax fermentans gen. nov., sp. nov., a phototrophic purple nonsulfur bacterium previously referred to as the "Rhodocyclus gelatinosus-like" group. Arch. Microbiol. 155:330-336.

14. Hiraishi, A., and H. Kitamura. 1984. Distribution of phototrophic purple nonsulfur bacteria in activated sludge systems and other aquatic environments. Bull. Jpn. Soc. Sci. Fish. 50:1929-1937.

15. Hiraishi, A., Y. K. Shin, Y. Ueda, and J. Sugiyama. 1994. Automated sequencing of PCR-amplified 16S rDNA on "Hydrolink" gels. J. Microbiol. Methods 19:145-154.

16. Hiraishi, A., and Y. Ueda. 1994. Intrageneric structure of the genus Rhodobacter: transfer of Rhodobacter sulfidophilus and related marine species to the genus Rhodovulum gen. nov. Int. J. Syst. Bacteriol. 44:15-25.

17. Hiraishi, A., and Y. Ueda. 1994. Rhodoplanes gen. nov., a new genus of phototrophic bacteria including Rhodopseudomonas rosea as Rhodoplanes roseus comb. nov. and Rhodoplanes elegans sp. nov. Int. J. Syst. Bacteriol. 44:665-673.

18. Imhof, J. F. 1983. Rhodopseudomonas marina sp. nov., a new marine phototrophic purple bacterium. Syst. Appl. Microbiol. 4:512-521.

19. Imhoff, J. F. 1984. Quinone of phototrophic purple bacteria. FEMS Microbiol. Lett. 25:85-89.

20. Imhoff, J. F., and H. G. Trüper. 1992. The genus Rhodospirillum and related genera, p. 2141-2155. In A. Balow, H. G. Tüper, M. Dworkin, W. Harder, and K.-H. Schleifer (ed.), The prokaryotes, 2 nd ed. Springer-Verlag, Berlin.

21. Imhoff, J. F., H. G. Trüper, and N. Pfennig. 1984. Rearrangements of the species and genera of the phototrophic "purple nonsulfur bacteria." Int. J. Syst. Bacteriol. 34:340-343.

22. Janssen, P. H., and C. G. Harfoot. 1991. Rhodopseudomonas rosea sp. nov., a new purple nonsulfur bacterium. Int. J. Syst. Bacteriol. 41:26-30. 
23. Kato, S., T. Urakami, and K. Komagata. 1985. Quinone systems and cellular fatty acid composition in species of Rhodospirillaceae genera. J. Gen. Appl. Microbiol. 31:381-398.

24. Kawasaki, H., Y. Hoshino, A. Hirata, and K. Yamasato. 1993. Is intracytoplasmic membrane structure a generic criterion? It does not coincide with phylogenetic interrelationships among phototrophic purple nonsulfur bacteria. Arch. Microbiol. 160:358-362.

25. Kimura, M. 1980. A simple method for estimating evolutionary rates of base substitution through comparative studies of nucleotide sequences. J. Mol. Evol. 16:111-120.

26. Klemme, J. H., I. Chyla, and M. Preuss. 1980. Dissimilatory nitrate reduction by strains of the facultative phototrophic bacterium Rhodopseudomonas palustris. FEMS Microbiol. Lett. 9:137-140.

27. Mangels, L. A., J. L. Favinger, M. T. Madigan, and H. Gest. 1986. Isolation and characterization of the $\mathrm{N}_{2}$-fixing marine photosynthetic bacterium Rhodopseudomonas marina, variety agilis. FEMS Microbiol. Lett. 36:99-104.

28. Marmur, J. 1961. A procedure for the isolation of deoxyribonucleic acid from micro-organisms. J. Mol. Biol. 3:208-218.

29. Orso, S., M. Gouy, E. Navarro, and P. Normand. 1994. Molecular phylogenetic analysis of Nitrobacter spp. Int. J. Syst. Bacteriol. 44:83-86.

30. Roppel, J., H. Mayer, and J. Wekesser. 1975. Identification of a 2,3-diamino2,3-dideoxyhexose in the lipid A component of lipopolysaccharides of Rhodopseudomonas viridis and Rhodopseudomonas palustris. Carbohydr. Res. 40:31-40.

31. Saitou, N., and M. Nei. 1987 . The neighbor-joining method: a new method for reconstructing phylogenetic trees. Mol. Biol. Evol. 4:406-425.

32. Satoh, T., Y. Hoshino, and H. Kitamura. 1976. Rhodopseudomonas sphaeroides forma sp. denitrificans, a denitrifying strain as a subspecies of Rhodopseudomonas sphaeroides. Arch. Microbiol. 108:265-269.

33. Seewaldt, E. K. H. Schleifer, E. Bock, and E. Stackebrandt. 1982. The close phylogenetic relationship of Nitrobacter and Rhodopseudomonas palustris. Arch. Microbiol. 131:287-290.

34. Tegtmeyer, B., J. Weckesser, H. Mayer, and J. F. Imhoff. 1985. Chemical composition of the lipopolysaccharides of Rhodobacter sulfidophilus, Rhodopseudomonas acidophila, and Rhodopseudomonas blastica. Arch. Microbiol. 143:32-36.

35. Trüper, H. G., and J. F. Imhoff. 1989. Genus Rhodopseudomonas Kluyver and van Niel in Czurda and Maresch 1937, $119^{\mathrm{AL}}$, p. 1672-1677. In J. T. Staley, M. P. Bryant, N. Pfennig, and J. G. Holt (ed.), Bergey's manual of systematic bacteriology, vol. 3. The Williams \& Wilkins Co., Baltimore.

36. Woese, C. R. 1987. Bacterial evolution. Microbiol. Rev. 51:221-271.

37. Woese, C. R., E. Stackebrandt, W. G. Weisburg, B. J. Paster, M. T. Madigan, V. J. Fowler, C. M. Hahn, P. Blanz, R. Gupta, K. H. Nealson, and G. E. Fox. 1984. The phylogeny of purple bacteria: the alpha subdivision. Syst. Appl. Microbiol. 5:315-326.

38. Wong, F. Y. K., E. Stackebrandt, J. K. Ladha, D. E. Fleischman, R. A. Date, and J. A. Fuerst. 1994. Phylogenetic analysis of Bradyrhizobium japonicum and photosynthetic stem-nodulating bacteria from Aeschynomene species grown in separated geographical regions. Appl. Environ. Microbiol. 60:940946. 